\title{
Constitutive histone H2AX phosphorylation on Ser-139 in cells untreated by genotoxic agents is cell-cycle phase specific and attenuated by scavenging reactive oxygen species
}

\author{
XUAN HUANG ${ }^{1}$, TOSHIKI TANAKA ${ }^{1,3}$, AKIRA KUROSE ${ }^{1,2,4}$, \\ FRANK TRAGANOS $^{1}$ and ZBIGNIEW DARZYNKIEWICZ ${ }^{1}$
}

\begin{abstract}
${ }^{1}$ Brander Cancer Research Institute and ${ }^{2}$ Department of Pathology, New York Medical College, Valhalla, NY 10595, USA; ${ }^{3}$ First Department of Surgery, Yamaguchi University School of Medicine, 1-1-1 Minami-kogushi, Ube, Yamaguchi 755-8505; ${ }^{4}$ Department of Pathology, Iwate Medical University, 19-1 Uchimaru, Morioka, Iwate 020-8505, Japan
\end{abstract}

Received February 3, 2006; Accepted March 30, 2006

\begin{abstract}
DNA damage, particularly when it involves formation of double-strand breaks (DSBs), triggers phosphorylation of histone H2AX on Ser-139. Phosphorylated $\mathrm{H} 2 \mathrm{AX}$ has been named $\gamma \mathrm{H} 2 \mathrm{AX}$, and induction of $\gamma \mathrm{H} 2 \mathrm{AX}$ in cells exposed to genotoxic agents is considered a sensitive and specific reporter of DNA damage. However, in untreated normal cells as well in the cells of various tumor lines cells, a fraction of histone $\mathrm{H} 2 \mathrm{AX}$ molecules remain phosphorylated. In the present study, we observed that the extent of this constitutive $\mathrm{H} 2 \mathrm{AX}$ phosphorylation varies depending on the cell type (line) and on cell cycle phase and, in most cell types, $S$ and $G_{2} / M$ phase cells exhibit greater levels of $H 2 A X$ phosphorylation than do cells in the $\mathrm{G}_{1}$ phase. Furthermore, constitutive H2AX phosphorylation in human pulmonary carcinoma A549, lymphoblastoid TK6, and in normal bronchial epithelial cells was reduced following cell exposure to $\mathrm{N}$-acetyl-L-cysteine, a scavenger of reactive oxygen intermediates; the reduction was most pronounced for $\mathrm{G}_{2} \mathrm{M}$ cells. Growth of A549 cells in the presence of buthionine sulfoximine, an inhibitor of glutathione synthetase, amplified the level of constitutive $\mathrm{H} 2 \mathrm{AX}$ phosphorylation in A549 cells. The observed constitutive H2AX phosphorylation may be a reflection of the ongoing DNA damage mediated by reactive oxygen species (ROS) generated by metabolic activity during progression through the cell cycle, leading to formation of DSBs during the S phase. Because cumulative DNA
\end{abstract}

Correspondence to: Dr Z. Darzynkiewicz, Brander Cancer Research Institute at NYMC, 19 Bradhurst Avenue, Suite 2400, Hawthorne, NY 10532, USA

E-mail: darzynk@nymc.edu

Key words: DNA repair, DNA damage, DNA replication, DNA double-strand breaks, cell cycle, free radicals, ROIs, antioxidants, oxidative stress, $\mathrm{S}$ phase, mitosis, chromatin, laser scanning cytometry, iCys damage in proliferating cells mediated by ROS is considered the key mechanism for cell ageing, the present approach to estimate the degree of attenuation of constitutive H2AX phosphorylation by antioxidants may provide a convenient tool to assess the DNA-protective and possible anti-ageing properties of other agents.

\section{Introduction}

Histone $\mathrm{H} 2 \mathrm{AX}$, one of the variants of the nucleosome core histone H2A (1-3), undergoes phosphorylation on Ser-139 in response to DNA damage, particularly if the damage involves formation of DNA double-strand breaks (DSBs) $(4,5)$. The phosphorylation, which is mediated by the PI-3-like kinases ATM- (4-7), ATR- (8) and/or DNA-dependent protein kinase (DNA-PK) (9), affects H2AX molecules at megabase DNA domains on both sides of DSBs in chromatin $(4,5)$. The Ser139-phosphorylated $\mathrm{H} 2 \mathrm{AX}$ has been defined as $\gamma \mathrm{H} 2 \mathrm{AX}(10)$.

The presence of $\gamma \mathrm{H} 2 \mathrm{AX}$ in chromatin can be detected immunocytochemically $(5,10)$. Shortly after DNA damage (e.g. by ionizing radiation), the induction of $\gamma \mathrm{H} 2 \mathrm{AX}$ manifests in the form of distinct nuclear $\gamma \mathrm{H} 2 \mathrm{AX}$ immunofluorescent (IF) foci $(5,10)$. Each focus is presumed to correspond to a single DSB. Numerous signaling and repair proteins including the $\mathrm{M} / \mathrm{R} / \mathrm{N}$ complex (Mre11/Rad50/Nbs1), Brca1 and the p53 binding protein 1 (53BP1) co-localize with phosphorylated $\mathrm{H} 2 \mathrm{AX}$ at the foci $(7-9,11-13)$. While $\mathrm{H}_{2} \mathrm{AX}^{-/}$cells fail to form irradiation-induced foci (14), the migration of repair and signaling proteins to DSBs is not abrogated in these cells. This would suggest that the $\mathrm{M} / \mathrm{R} / \mathrm{N}$ complex itself provides the mechanism for migration of these proteins. The loss of $\mathrm{H} 2 \mathrm{AX}$ in mice, however, leads to genomic instability. $\mathrm{H} 2 \mathrm{AX}^{-/-}$mice are radiation sensitive, growth-retarded, and immunodeficient (15). Even H2AX haploinsufficiency compromises the genetic integrity of the mice, and enhances their susceptibility to cancer, particularly in the absence of p53 (16). H2AX is thus one of the critical proteins responsible for surveillance of genome integrity (17).

$\mathrm{H} 2 \mathrm{AX}$ is also phosphorylated in physiological processes that involve DNA recombination. This occurs in response to 
formation of DSBs in V(D)J and class-switch recombination during immune system development and also at sites of recombinational DSB formation in meiosis (18-21). The multiplicity of DSBs generated during DNA fragmentation in apoptotic cells also induces $\mathrm{H} 2 \mathrm{AX}$ phosphorylation (22). The extent of $\mathrm{H} 2 \mathrm{AX}$ phosphorylation during apoptosis is much greater compared to the $\mathrm{H} 2 \mathrm{AX}$ phosphorylation induced by particular genotoxic agents (22-25).

In untreated normal cells and in cells of various tumor lines, a fraction of histone $\mathrm{H} 2 \mathrm{AX}$ molecules remain phosphorylated. The extent of this constitutive ('programmed', 'intrinsic') H2AX phosphorylation, which can be detected immunocytochemically, varies depending on the cell type (line) and cell cycle phase (24-26). Generally, cells in S phase as well as mitotic cells exhibit much greater levels of H2AX phosphorylation than $\mathrm{G}_{1}$ cells. However, in contrast to the cells in which $\mathrm{H} 2 \mathrm{AX}$ phosphorylation is induced by DNA damage, there is no evidence of discrete and strongly fluorescent nuclear $\gamma \mathrm{H} 2 \mathrm{AX}$ foci. Instead, the constitutive H2AX phosphorylation appears in the form of diffuse, weakly fluorescent heteromorphous structures distributed over the entire nucleus (23-26).

It is generally recognized that cells are continuously exposed to oxidants generated by metabolic activity and other biochemical reactions as well as to external oxidants or oxidant-inducers. It is also recognized that oxidative stress induces DNA damage. In fact, progressive oxidative DNA damage has been considered one of the primary factors of ageing (27-29). The present study was designed to explore whether the observed constitutive $\mathrm{H} 2 \mathrm{AX}$ phosphorylation in untreated cells may be a reflection of the ongoing DNA damage induced in untreated cells by oxidative stress during the cell cycle. If this is the case, one would expect that depletion of free radicals will attenuate the constitutive $\mathrm{H} 2 \mathrm{AX}$ phosphorylation. We have tested, therefore, whether exposure of cells to an antioxidant, the free radicals scavenger $\mathrm{N}$-acetyl-L-cysteine (NAC), may have such an effect. Furthermore, to explore whether the intrinsic oxidant scavenger, glutathione, plays a role in reducing DNA damage that can be revealed by the level of constitutive $\mathrm{H} 2 \mathrm{AX}$ phosphorylation, we have measured the effect of inhibition of glutathione synthesis by the synthetase inhibitor, buthionine sulfoximine (BSO), on expression of $\gamma \mathrm{H} 2 \mathrm{AX}$ in relation to the cell cycle phase.

\section{Materials and methods}

Cells and culture conditions. Human lymphoblastoid TK6 were kindly provided by Dr Howard Liber of Colorado State University, Fort Collins Co. Jurkat cells were purchased from American Type Culture Collection (ATCC; Manassas, VA). They were grown in $25 \mathrm{ml}$ Falcon flasks (Becton-Dickinson Co., Franklin Lakes, NJ) in RPMI-1640 supplemented with $10 \%$ fetal calf serum, 100 units $/ \mathrm{ml}$ penicillin, $100 \mu \mathrm{g} / \mathrm{ml}$ streptomycin and $2 \mathrm{mM}$ L-glutamine (all from Gibco/BRL Life Technologies, Inc., Grand Island, NY) at $37^{\circ} \mathrm{C}$ in an atmosphere of $5 \% \mathrm{CO}_{2}$ in air. At the onset of the experiments, there were fewer than $5 \times 10^{5}$ cells per $\mathrm{ml}$ in culture and the cells were at an exponential and asynchronous phase of growth. DU145, HeLa, MCF-7 and A549 cells were obtained from ATCC and were grown in Dulbecco's minimum essential medium (DMEM) supplemented with $10 \%$ fetal bovine serum,
100 units/ml penicillin, $100 \mu \mathrm{g} / \mathrm{ml}$ streptomycin and $2 \mathrm{mM}$ L-glutamine (Gibco/BRL). Human normal bronchial epithelial cells (HNBE) were purchased from Cambrex BioScience, Walkersville, MD, and were cultured in complete bronchial epithelial cell growth medium (BEGM), prepared by supplementing bronchial epithelial basal medium (BEBM) with retinoic acid, human epidermal growth factor, epinephrine, transferrin, triiodothyronine, insulin, hydrocortisone, bovine pituitary extract and gentamicin by addition of SingleQuots ${ }^{\mathrm{TM}}$. BEBM and SingleQuots ${ }^{\mathrm{TM}}$ were purchased from Cambrex BioScience. The cultures were diluted and replated every 4 days to maintain them in an asynchronous and exponential phase of growth. For experiments, the cells were trypsinized and seeded at low cell density $\left(\sim 5 \times 10^{4}\right.$ cells per chamber $)$ in 2-chambered Falcon CultureSlides (Beckton-Dickinson Labware, Franklin Lakes, NJ).

Cell treatments. NAC was obtained from Sigma Chemical Co. (St. Louis, MO). The $\mathrm{pH}$ of the NAC solution was adjusted to 7.0 before being applied to the cells. The cultures were incubated with various concentrations of NAC for different time intervals, as described in the figure legends. To inhibit GSH synthesis, the cultures were incubated with $100 \mu \mathrm{M}$ BSO (Sigma) for $17 \mathrm{~h}$. The cells were then fixed either in suspension or by transferring the slides into Coplin jars containing 1\% methanol-free formaldehyde (Polysciences, Inc., Warrington, PA) in PBS for $15 \mathrm{~min}$ on ice followed by suspension in $70 \%$ ethanol, where they were stored at $-20^{\circ} \mathrm{C}$ for 2-24 h.

Immunocytochemical detection of $\gamma H 2 A X$. The fixed cells were washed twice in PBS and suspended in $0.2 \%$ Triton $\mathrm{X}-100$ (Sigma) in a 1\% (w/v) solution of bovine serum albumin (BSA; Sigma) in PBS for $30 \mathrm{~min}$ to suppress nonspecific antibody $(\mathrm{Ab})$ binding. The cells were then incubated in $100 \mu \mathrm{l}$ of 1\% BSA containing 1:200 diluted anti-phospho-histone H2A.X (Ser-139) mAb (Upstate, Lake Placid, NY). The cells were then incubated overnight at $4^{\circ} \mathrm{C}$, washed twice with PBS and resuspended in $100 \mu 1$ of 1:30 diluted FITC-conjugated $\mathrm{F}\left(\mathrm{ab}^{\prime}\right) 2$ fragment of goat anti-mouse immunoglobulin (Dako) for $30 \mathrm{~min}$ in room temperature in the dark. The cells were then counterstained with either $1 \mu \mathrm{g} / \mathrm{ml} \mathrm{4,6-diamidino-2-}$ phenylindole (DAPI, Molecular Probes) in PBS for $5 \mathrm{~min}$, or $5 \mu \mathrm{g} / \mathrm{ml} \mathrm{PI}$ in the presence of $100 \mu \mathrm{g} / \mathrm{ml}$ of RNase A (Sigma).

Fluorescence measurements. Cellular green (FITC) and blue (DAPI) fluorescence emission was measured simultaneously in the same cells using an iCys laser scanning cytometer (LSC) (CompuCyte, Cambridge, MA) utilizing standard filter settings; fluorescence was excited with 488-nm argon ion and violet diode lasers, respectively. The intensities of maximal pixel and integrated fluorescence were measured and recorded for each cell. At least 3,000 cells were measured per sample. Cellular green (FITC) and red (PI) fluorescence of cells in suspension was measured using a FACScan flow cytometer (Becton-Dickinson, San Jose, CA). The red (PI) and green (FITC) fluorescence from each cell were separated and quantified using standard optics and CellQuest software (Becton-Dickinson). Each experiment was run in duplicate or triplicate and repeated at least three times. 


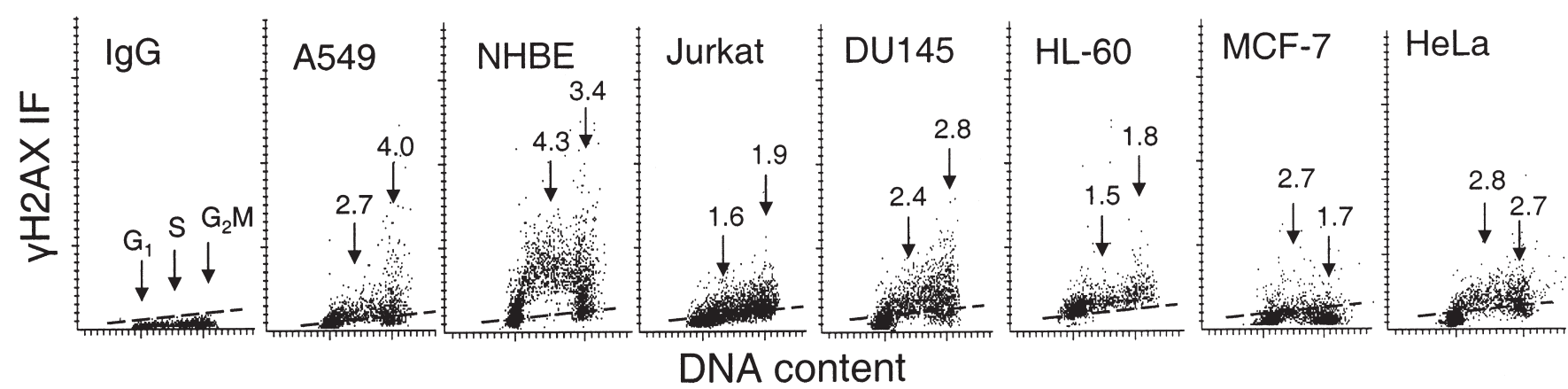

Figure 1. Different level and cell cycle phase variability of constitutive H2AX phosphorylation observed in different cell types. Bivariate distributions representing cellular DNA content vs $\gamma \mathrm{H} 2 \mathrm{AX}$ IF of human cells from untreated exponentially growing lung carcinoma A549, normal bronchial epithelial (NHBE), T-cell leukemic Jurkat, prostate carcinoma DU145, promyelocytic leukemic HL-60, breast carcinoma MCF-7 and cervical carcinoma HeLa cell cultures measured by laser-scanning cytometry. The negative isotype control (IgG; A549 cells) is shown in the left panel. Other cell types had similarly low nonspecific fluorescence; the maximal level of IgG IF, below which $>97 \%$ of cells in the IgG panel were located, is marked in each panel by a dashed line. The figures above the arrows pointing to $S$ and $G_{2} M$ cells indicate the n-fold higher mean expression of $\gamma \mathrm{H} 2 \mathrm{AX}$ of $\mathrm{S}$ - and $\mathrm{G}_{2} \mathrm{M}$-phase cells, respectively, compared to $\mathrm{G}_{1}$ cells, whose mean $\gamma \mathrm{H} 2 \mathrm{AX}$ for each cell type was normalized to 1.0. To allow for comparison of the differences in $\gamma \mathrm{H} 2 \mathrm{AX}$ IF intensity, fluorescence measurements were carried out at the same laser power output and photomultiplier sensitivity. Note differences in the extent and pattern of $\gamma \mathrm{H} 2 \mathrm{AX}$ expression vis-à-vis the cell cycle phase in different cell types. NHBE cells in the $\mathrm{S}$ phase of the cycle exhibit a particularly high expression of $\gamma \mathrm{H} 2 \mathrm{AX}$.
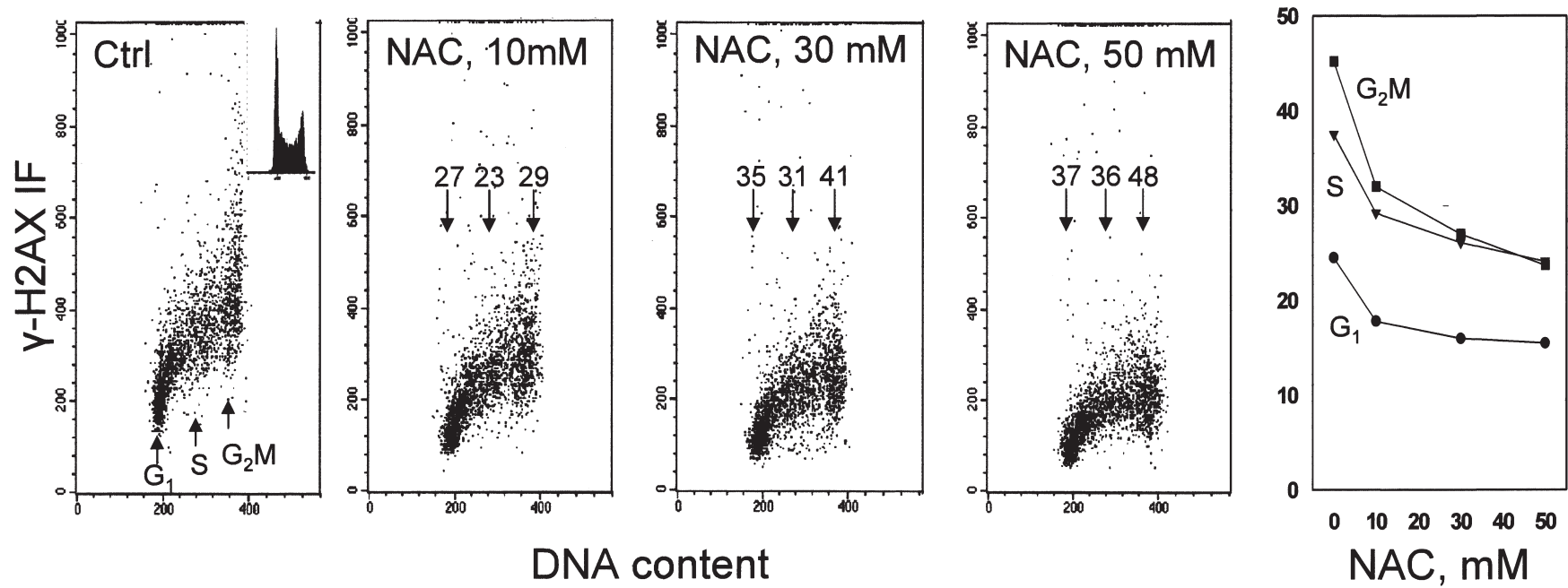

Figure 2. Decrease in expression of $\gamma \mathrm{H} 2 \mathrm{AX}$ in TK6 cells induced by their growth in the presence of different concentrations of NAC. The first four panels show bivariate distributions illustrating cellular DNA content vs $\gamma \mathrm{H} 2 \mathrm{AX}$ expression of cells growing in the absence (Ctrl) or presence of 10,30 or 50 mM NAC, included into cultures for $1 \mathrm{~h}$ prior to cell harvesting. The figures above arrows pointing to $\mathrm{G}_{1}, \mathrm{~S}$, and $\mathrm{G}_{2} \mathrm{M}$ cells indicate percent decrease of means of $\gamma \mathrm{H} 2 \mathrm{AX}$ IF of cells in these phases of the cycle in the NAC-treated cultures with respect to the Ctrl. The right panel presents the plot of the mean values of $\gamma \mathrm{H} 2 \mathrm{AX}$ expression estimated for $\mathrm{G}_{1}, \mathrm{~S}$ and $\mathrm{G}_{2} \mathrm{M}$ cell populations by gating analysis of the raw data shown in the left panels, as a function of $\mathrm{NAC}$ concentration.

\section{Results}

Using $\mathrm{Ab}$ that specifically binds to the epitope of histone H2AX phosphorylated on Ser-139, the presence of the phosphorylated form of this histone was detected immunocytochemically in a variety of cell types (Fig. 1). The cells were from cultures growing exponentially and were not subjected to treatment with any genotoxic agent. Concurrent differential staining of cellular DNA and measurement of cellular fluorescence by LSC made it possible to correlate expression of $\gamma \mathrm{H} 2 \mathrm{AX}$ with cell cycle phase. The data show that $\gamma \mathrm{H} 2 \mathrm{AX}$ expression varied markedly depending on the cell type and cell cycle phase. Some cell types, such as NHBE, A549 or DU145, showed distinctly higher levels of $\gamma \mathrm{H} 2 \mathrm{AX}$ expression than Jurkat, MCF-7 or HL-60 cells. Among the cell types strongly expressing $\gamma \mathrm{H} 2 \mathrm{AX}, \mathrm{S}$-phase cells and a fraction of cells in $\mathrm{G}_{2} \mathrm{M}$ exhibited higher levels of $\mathrm{H} 2 \mathrm{AX}$ phosphorylation compared to G1 cells.

More detailed analysis of constitutive H2AX phosphorylation vis-à-vis cell cycle phase was performed for TK6, A549 and NHBE cells. In several independent experiments, subpopulations of cells in $G_{1}$, early-, mid-, and late-S and $G_{2} M$ were selected by gating analysis and the mean values of $\gamma \mathrm{H} 2 \mathrm{AX}$ IF for these subpopulations were estimated. The data were normalized to $G_{1}$ cells (1.00) to represent $n$-fold change in $\gamma \mathrm{H} 2 \mathrm{AX}$ expression that occurs during progression through $\mathrm{S}$ and $\mathrm{G}_{2} \mathrm{M}$. It is quite evident that the extent of phosphorylated $\mathrm{H} 2 \mathrm{AX}$ progressively increased when cells advanced through 


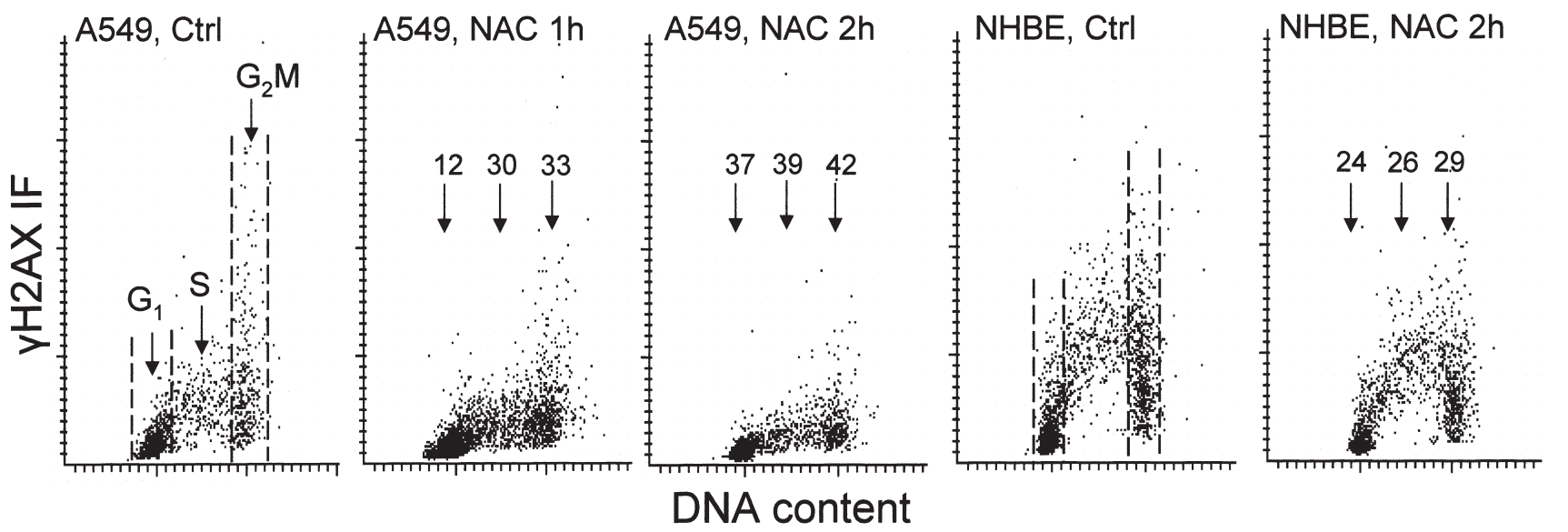

Figure 3. NAC-induced decrease in expression of $\gamma \mathrm{H} 2 \mathrm{AX}$ in A549 and HNBE cells. The bivariate cellular DNA content vs $\gamma \mathrm{H} 2 \mathrm{AX}$ IF distributions represent untreated (Ctrl) A549 or NHBE cells and the cells growing in the presence of $25 \mathrm{mM} \mathrm{NAC}$ for $1 \mathrm{or} 2 \mathrm{~h}$. As in Fig. 2, the figures over the arrows pointing towards $G_{1}, S$ and $G_{2} M$ cells indicate the percent decrease of means of H2AX IF of cell in these phases in the NAC-treated cultures with respect to the respective Ctrl.
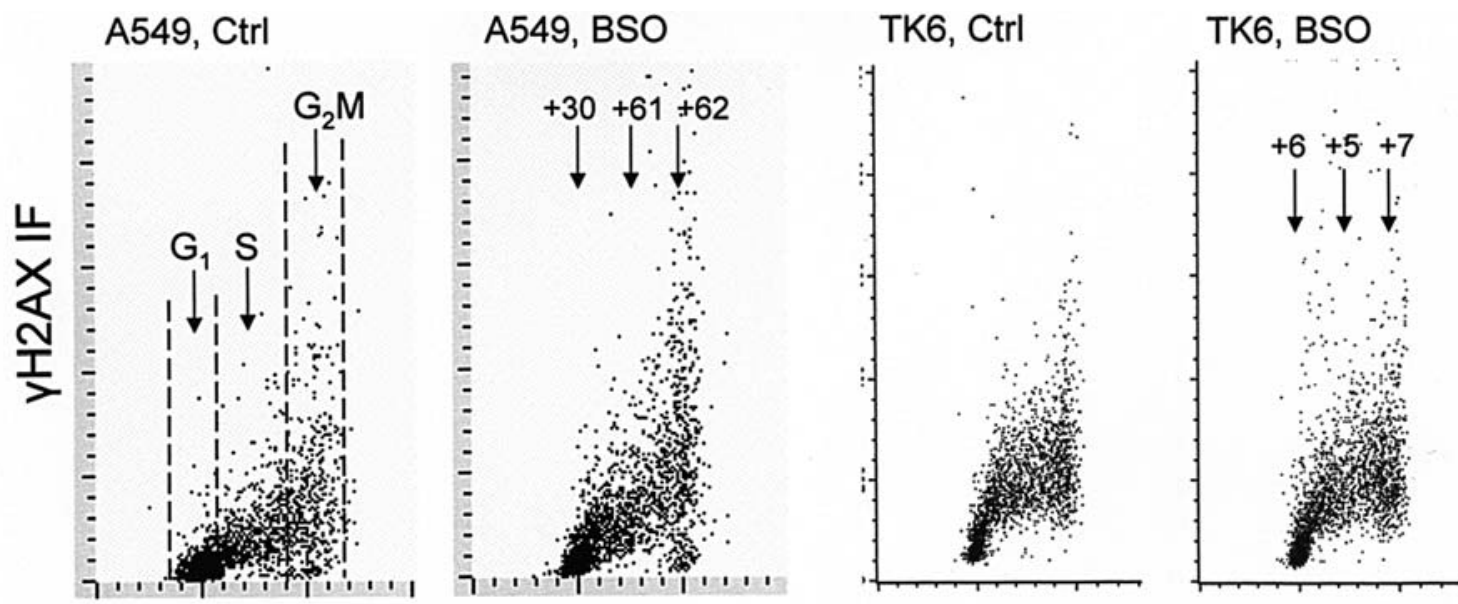

\section{DNA content}

Figure 4. Effect of growth in the presence of BSO on expression of $\gamma \mathrm{H} 2 \mathrm{AX}$ in A549 and TK6 cells. Exponentially growing A549 and TK6 cells were exposed in cultures to $100 \mu \mathrm{M}$ BSO for 17 or $21 \mathrm{~h}$, respectively, prior to harvesting. Fluorescence of A549 cells was measured by LSC and fluorescence of TK3 cells by flow cytometry. The mean $\gamma \mathrm{H} 2 \mathrm{AX}$ IF of cells gated in $\mathrm{G}_{1}, \mathrm{~S}_{\text {and }} \mathrm{G}_{2} \mathrm{M}$ phase was measured and is expressed in the BSO-treated cultures as percent increase above the respective means in Ctrl.

$\mathrm{S}$ and, in NHBE cells, peaked at late-S phase. In the case of TK6 and A549 cells, the maximal expression of $\gamma \mathrm{H} 2 \mathrm{AX}$ was in $\mathrm{G}_{2} \mathrm{M}$ cells.

Growth of TK6 cells in the presence of NAC for $1 \mathrm{~h}$ reduced their expression of $\gamma \mathrm{H} 2 \mathrm{AX}$ in an NAC concentrationdependent manner (Fig. 2). The effect was already seen at $10 \mathrm{mM}$ NAC, and was most pronounced for $\mathrm{G}_{2} \mathrm{M}$ phase cells, whose mean $\gamma \mathrm{H} 2 \mathrm{AX}$ IF was reduced by $48 \%$ at $50 \mathrm{mM}$ NAC. Under the same culture conditions, the decrease in $\gamma \mathrm{H} 2 \mathrm{AX}$ IF of $\mathrm{G}_{1}$ - and S-phase cells was 37 and $36 \%$, respectively.

The expression of $\gamma \mathrm{H} 2 \mathrm{AX}$ was also reduced in A549 and NHBE cells that were grown in the presence of NAC (Fig. 3). Although the differences between $G_{1}$ vs $S$ vs $G_{2} M$ in the degree of reduction of $\mathrm{H} 2 \mathrm{AX}$ expression were smaller than in the case of TK6 cells (Fig. 2), in every instance, the reduction was most pronounced for $\mathrm{G}_{2} \mathrm{M}$ cells.
Growth of A549 cells in the presence of $100 \mu \mathrm{M}$ BSO for the approximate duration of one cell cycle $(17 \mathrm{~h})$ led to a distinct increase in expression of $\gamma \mathrm{H} 2 \mathrm{AX}$ (Fig. 4). The increase was more pronounced for $\mathrm{S}$ - and $\mathrm{G}_{2} \mathrm{M}$-phase cells (61-62\%) than for $\mathrm{G}_{1}$-phase cells (30\%). In the case of TK6 cells, however, the effect of BSO was minimal.

\section{Discussion}

The present data confirm and extend the earlier observations of McPhail et al, (26) and our own findings (22-24) that the presence of histone H2AX phosphorylated on Ser-139 can be detected in a variety of cell types growing in cultures and not exposed to genotoxic agents. Histone $\mathrm{H} 2 \mathrm{AX}$ phosphorylation is being considered a specific and sensitive reporter of DNA damage, particularly the induction of DSBs (4-6). It is likely, 
Table I. The cell-cycle phase differences in the level of expression of $\gamma \mathrm{H} 2 \mathrm{AX}$ in different cell types.

\begin{tabular}{lccccc}
\hline Cells & $\mathrm{G}_{1}$ & Early-S & Mid-S & Late-S & $\mathrm{G}_{2} \mathrm{M}$ \\
\hline TK6 $(\mathrm{n}=3)$ & $1.00 \pm 0.19$ & $1.68 \pm 0.17$ & $1.86 \pm 0.16$ & $2.06 \pm 0.14$ & $2.22 \pm 0.19$ \\
A549 $(\mathrm{n}=5)$ & $1.00 \pm 0.02$ & $2.27 \pm 0.07$ & $2.79 \pm 0.06$ & $3.25 \pm 0.17$ & $3.87 \pm 0.22$ \\
HNBE $(\mathrm{n}=5)$ & $1.00 \pm 0.04$ & $3.50 \pm 0.15$ & $4.50 \pm 0.17$ & $4.68 \pm 0.11$ & $3.41 \pm 0.08$ \\
\hline
\end{tabular}

Expression of $\gamma \mathrm{H} 2 \mathrm{AX}$ was measured in TK6, A549 and NHBE cells concurrently with cellular DNA content by flow (TK6) or laserscanning (A549 and NHBE) cytometry, as shown in the raw data in Fig. 1. The mean values of H2AX expression were then estimated for cell populations gated based on differences in DNA content (DNA index; DI) as follows: $\mathrm{G}_{1}(\mathrm{DI}=0.9-1.1)$, early-S (DI=1.1-1.4), mid-S (DI=1.4-1.6), late-S (1.6-1.9) and $\mathrm{G}_{2} \mathrm{M}(\mathrm{DI}=1.9-2.1)$. The data were normalized to the mean value of $\mathrm{G}_{1}$ cells $(1.00)$ of the respective cell type. The analysis was carried out on several $(n=3$ or 5$)$ different cultures for each cell type and the data show mean values \pm SE of these separate analyses.

therefore, that the observed $\mathrm{H} 2 \mathrm{AX}$ phosphorylation in the untreated cells is a marker of constitutive DNA damage that occurs during progression through the cell cycle and leads to formation of DSBs. It has been estimated that $~ 50$ DSBs per nucleus (which amounts to $\sim 0.8 \mathrm{DSBs}$ per $108 \mathrm{bp}$ ) are generated during a single cell cycle in human cells untreated with any exogenous genotoxic agent (30). This estimate of constitutive formation of DSBs, called 'endogenous DSBs', was based on an assumption that $\sim 1 \%$ of single-strand lesions (SSLs) are converted to DSBs during the cell cycle (30), and also by calculating the dose of $\mathrm{X}$-irradiation (IR) that doubles the extent of $\mathrm{H} 2 \mathrm{AX}$ phosphorylation (number of $\gamma \mathrm{H} 2 \mathrm{AX}$ foci per nucleus), interpolating the IR to dose zero and, thereby, estimating the magnitude of the background H2AX phosphorylation in non-irradiated cells in terms of number of DSBs (30).

In the present study, we observed that the level of H2AX phosphorylation varied between cell lines and also between cells, depending on their position in the cell cycle (Fig. 1). Interestingly, normal (non-tumor) NHBE cells exhibited the highest level of constitutive $\mathrm{H} 2 \mathrm{AX}$ phosphorylation, distinctly higher than cells of each of the six tumor lines. Compared to $\mathrm{G}_{1}$-phase cells, which served as a yardstick (1.0) to relate the relative level of $\gamma \mathrm{H} 2 \mathrm{AX}$ expression in $\mathrm{S}$ - and $\mathrm{G}_{2} \mathrm{M}$-phase cells, $\mathrm{G}_{2} \mathrm{M}$ cells of the A549 line and S-phase NHBE cells showed the highest level of H2AX phosphorylation (4.1- and 3.9-fold, respectively).

In several cell lines (A549, NHBE, DU145) a minor fraction of $\mathrm{G}_{2} \mathrm{M}$ cells showed high levels of $\gamma \mathrm{H} 2 \mathrm{AX}$ expression. As shown by us (31) and others $(32,33)$, the strongly $\gamma \mathrm{H} 2 \mathrm{AX}$ positive cells were mitotic cells. $\mathrm{H} 2 \mathrm{AX}$ phosphorylation observed in mitotic cells from cultures untreated by genotoxic agents is considered unrelated to DNA damage. Its function was postulated to be related to preservation of fidelity of the mitotic process, even in the absence of DNA damage (32). However, chromatin condensation during mitosis induces torsional stress on the DNA superhelical structure, which manifests by increased sensitivity of mitotic cell DNA to single-strand specific nucleases (34), and upon exposure to heat or acid, in increased susceptibility to denaturation (melting) $(35,36)$. It is possible, therefore, that the observed $\mathrm{H} 2 \mathrm{AX}$ phosphorylation in mitotic cells is triggered by this conformational DNA change that is associated with its tight packing in the condensed chromatin in mitotic chromosomes that causes torsional topological stress on DNA. Similar topological stress (melting transitions) induced in DNA by T4 gene 32 protein was recently measured by single molecule force spectroscopy (37). It is likely that local DNA pre-melting conformational changes that may occur when subjecting mammalian cells to heat shock are also responsible for the induction of $\mathrm{H} 2 \mathrm{AX}$ phosphorylation in these cells (38).

Parallel to DNA content, histone content also doubles during the cell cycle. The observed increase in $\gamma \mathrm{H} 2 \mathrm{AX}$ expression in $\mathrm{S}$ - and $\mathrm{G}_{2} \mathrm{M}$-phase cells thus reflects both, the increase in $\mathrm{H} 2 \mathrm{AX}$ content and the increased degree of its phosphorylation (per unit of $\mathrm{H} 2 \mathrm{AX}$ protein). To estimate the mean degree of $\mathrm{H} 2 \mathrm{AX}$ phosphorylation in a particular phase of the cell cycle, one thus has to compensate for the increase in $\mathrm{H} 2 \mathrm{AX}$ content during the cell cycle and thereby divide the mean increases of $\gamma \mathrm{H} 2 \mathrm{AX}$ expression in $\mathrm{S}$ and $\mathrm{G}_{2} \mathrm{M}$ cells related to $G_{1}$ cells, as marked in Fig. 1, by 1.5 and 2.0, respectively. Following such compensation, one may conclude that no significant increase in the degree of H2AX phosphorylation during the cell cycle occurred in some cell types (Jurkat, HL-60). Although, in other cell types, the increase was seen only in S-phase cells (MCF-7), in most cell types (A549, NHBE, DU145, HeLa), the elevated degree of H2AX phosphorylation (above that of $\mathrm{G}_{1}$ cells) was seen in both, $\mathrm{S}$ - and $\mathrm{G}_{2} \mathrm{M}$-phase cells. A variety of factors associated with a cell's response to oxidative stress and DNA damage, such as the presence of wt p53 (39), or expression of other tumor suppressor- and onco-genes (40), known to vary between cell lines, may be responsible for the observed cell cycle-phase differences in constitutive $\mathrm{H} 2 \mathrm{AX}$ phosphorylation in the studied cell types.

Cell growth in the presence of NAC distinctly reduced the extent of constitutive H2AX phosphorylation. The reduction was apparent for all three cell types that were studied, lymphoblastoid TK6 cells (Fig. 2), pulmonary carcinoma A549 and normal bronchial epithelial cells (Fig. 3). NAC is considered an effective scavenger of ROIs and is widely used as a chemopreventive agent (reviewed in ref. 41). It is most likely that the observed reduction of $\mathrm{H} 2 \mathrm{AX}$ phosphorylation by NAC reflects a decreased rate of constitutive DNA damage by 
ROIs, which are scavenged by this antioxidant. Indeed, there is strong evidence that constitutive DNA damage during the cell cycle is mediated by $\operatorname{ROS}(27-30,42)$.

It should be noted, however, that NAC itself may cause DNA damage (41). The DNA damaging effect, however, was generally observed after prolonged $(18 \mathrm{~h})$ exposure of cells to this antioxidant. It is rather unlikely, thus, that significant DNA damage was induced by NAC in the present study, in which the duration of cell exposure to NAC did not exceed $2 \mathrm{~h}$.

In support of the notion that observed constitutive phosphorylation of $\mathrm{H} 2 \mathrm{AX}$ reflects DNA damage caused by ROS are the results showing its increased phosphorylation in A549 cells growing in the presence of $\mathrm{BSO}$, the agent expected to decrease the level of the intrinsic ROS scavenger, glutathione, in the cell. This effect, however, while distinct in A549 cells, was not evident in TK6 cells (Fig. 4). Perhaps the efficiency of ROS scavenging properties of the intracellular glutathione, e.g. due to differences in glutathione content per cell, or its accessibility to ROS, varies between the cell types, and is lower in TK6 than in A549 cells.

As mentioned, approximately $50 \mathrm{DSB}$ are generated during the cell cycle in human cells (30). They represent $\sim 1 \%$ of the SSLs initially induced by ROS, which become converted to DSBs during DNA replication; the remaining $99 \%$ of SSLs are repaired by error-free mechanisms (30). The generation of DSBs is thus a two-step dynamic process: (i) abundant production of SSL, followed by (ii) conversion of some SSLs into DSBs during the S phase. Our present findings, which indicate the highest degree of constitutive $\mathrm{H} 2 \mathrm{AX}$ phosphorylation in $\mathrm{S}$ and $\mathrm{G}_{2} \mathrm{M}$ cells and a progressive increase in the level of phosphorylated $\mathrm{H} 2 \mathrm{AX}$ in mid- and late-S phase as compared to early-S (Table 1), are consistent with this mechanism. Namely, as more and more DNA is replicated during progression through $S$ phase there is a cumulative production of DSBs triggering progressive phosphorylation of H2AX. Some of these DSBs may remain during $G_{2}$ and be responsible for a transient delay in progression of cells at the $\mathrm{G}_{2} \mathrm{M}$ checkpoint, where the repair of DSBs may occur.

Cumulative DNA damage in proliferating cells mediated by ROS is considered the key mechanism for cell ageing. The present data show that it is possible to measure the degree of attenuation of H2AX phosphorylation and, thus most likely, the degree of protection of DNA from the damage caused by intrinsic ROS. Therefore, this approach can be used to evaluate DNA-protective and possible anti-ageing properties of antioxidant agents other than NAC. It also can be used to assess whether oxidative stress mediates the DNAdamaging effect of the suspected genotoxic agent, as recently demonstrated in studies on the effects of tobacco smoke $(43,44)$.

\section{Acknowledgements}

This study was supported by NCI CA 28704.

\section{References}

1. West $\mathrm{MH}$ and Bonner WM: Histone 2A, a heteromorphous family of eight protein species. Biochemistry 19: 3238-3245, 1980 .
2. Thatcher TH and Gorovsky MA: Phylogenetic analysis of the core histones H2A, H2B, H3 and H4. Nucleic Acids Res 22: 174-179, 1994.

3. Pehrson JR and Fuji RN: Evolutionary conservation of histone macro-H2A subtypes and domains. Nucleic Acids Res 26: 2837-2842, 1998.

4. Rogakou EP, Pilch DR, Orr AH, Ivanova VS and Bonner WM: DNA double-stranded breaks induce histone H2AX phosphorylation on serine 139. J Biol Chem 273: 5858-5868, 1998.

5. Sedelnikova OA, Rogakou EP, Panuytin IG and Bonner W: Quantitive detection of 125IUdr-induced DNA double-strand breaks with $\gamma$-H2AX antibody. Radiat Res 158: 486-492, 2002.

6. Burma S, Chen BP, Murphy M, Kurimasa A and Chen DJ: ATM phosphorylates histone H2AX in response to DNA doublestrand breaks. J Biol Chem 276: 42462-42467, 2001.

7. Anderson L, Henderson C and Adachi Y: Phosphorylation and rapid relocalization of 53BP1 to nuclear foci upon DNA damage. Mol Cell Biol 21: 1719-2179, 2001.

8. Furuta T, Takemura H, Liao Z-Y, Aune GJ, Redon C, Sedelnikova OA, Pilch DR, Rogakou EP, Celeste A, Chen HT, Nussenzweig A, Aladjem MI, Bonner WM and Pommier Y: Phosphorylation of histone H2AX and activation of Mre11, Rad50, and Nbs1 in response to replication-dependent DNA double-strand breaks induced by mammalian topoisomerase I cleavage complexes. J Biol Chem 278: 20303-20312, 2003.

9. Park EJ, Chan DW, Park JH, Oettinger MA and Kwon J: DNAPK is activated by nucleosomes and phosphorylated H2AX within the nucleosomes in an acetylation-dependent manner. Nucleic Acids Res 31: 6819-6827, 2003.

10. Rogakou EP, Boon, C, Redon C and Bonner WM: Megabase chromatin domains involved in DNA double-strand breaks in vivo. J Cell Biol 146: 905-916, 1999.

11. Paull TT, Rogakou EP, Yamazaki V, Kirchgesser CU, Gellert M and Bonner WM: A critical role for histone $\mathrm{H} 2 \mathrm{AX}$ in recruitment of repair factors to nuclear foci after DNA damage. Curr Biol 10: 886-895, 2000.

12. Foster ER and Downs JA: Histone H2AX phosphorylation in DNA double-strand break repair. FEBS J 272: 3231-3240, 2005.

13. Downs JA and Cote J: Dynamics of chromatin during the repair of DNA double-strand breaks. Cell Cycle 4: 1373-1376, 2005.

14. Celeste A, Fernandez-Capetillo O, Kruhlak MJ, Pilch DR, Staudt DW, Lee A, Bonner RF, Bonner WM and Nussenzweig A: Histone H2AX phosphorylation is dispensable for the initial recognition of DNA breaks. Nat Cell Biol 5: 675-679, 2003.

15. Celeste A, Paterson S, Romanienko PJ, Fernandez-Capetillo O, Chen HT, Sedelnikov OA, Reina-San Martin B, Coppola V, Meffre E, Difilippantonio MJ, Redon C, Pilch DR, Olaru A, Eckhaus M, Camerini-Otero RD, Tessarollo L, Livak F, Manova K, Bonner WM, Nussenzweig MC and Nussenzweig A: Genomic instability in mice lacking histone H2AX. Science 296: 922-927, 2002 .

16. Celeste A, Difilippantonio S, Fernandez-Capetillo O, Pilch DR, Sedelnikova O, Eckhaus M, Ried T, Bonner WM and Nussenzweig A: H2AX haploinsufficiency modifies genomic stability and tumor susceptibility. Cell 114: 371-383, 2003.

17. Bassing $\mathrm{CH}$, Suh H, Ferguson DO, Chua KF, Manis J, Eckersdorff M, Gleason M, Bronson R, Lee C and Alt FW: Histone H2AX: A dosage-dependent suppressor of oncogenic translocations in tumors. Cell 114: 359-370, 2003.

18. Jackson SP: DNA damage signaling and apoptosis. Biochem Soc Trans 29: 655-661, 2001.

19. Fernandez-Capetillo O, Chen H-T, Celecte A, Ward I, Romanienko P, Morales JC, Naka K, Xia Z, Camerini-Otero RD, Motoyama N, Carpenter PB, Bonner WM, Chen J and Nussenzweig A: DNA damage-induced $\mathrm{G}_{2}-\mathrm{M}$ checkpoint activation by histone $\mathrm{H} 2 \mathrm{AX}$ and 53BP1. Nature Cell Biol 4: 993-997, 2002.

20. Modesti M and Kanaar R: DNA repair: spot(light)s on chromatin. Curr Biol 11: R229-R232, 2001.

21. Sedelnikova OA, Pilch DR, Redon C and Bonner WM: Histone H2AX in DNA damage and repair. Cancer Biol Ther 2: 233-235, 2003.

22. Huang X, Okafuji M, Traganos F, Luther E, Holden E and Darzynkiewicz Z: Assessment of histone H2AX phosphorylation induced by DNA topoisomerase I and II inhibitors topotecan and mitoxantrone and by DNA crosslinking agent cisplatin. Cytometry 58A: 99-110, 2004. 
23. Huang X, Halicka HD, Traganos F, Tanaka T, Kurose A and Darzynkiewicz Z: Cytometric assessment of DNA damage in relation to cell cycle phase and apoptosis. Cell Prolif 38: 223-243, 2005.

24. Huang X, Traganos F and Darzynkiewicz Z: DNA damage induced by DNA topoisomerase I- and topoisomerase IIinhibitors detected by histone $\mathrm{H} 2 \mathrm{AX}$ phosphorylation in relation to the cell cycle phase and apoptosis. Cell Cycle 2: 614-619, 2003.

25. Halicka HD, Huang X, Traganos F, King MA, Dai W and Darzynkiewicz Z: Histone H2AX phosphorylation after cell irradiation with UV-B: relationship to cell cycle phase and induction of apoptosis. Cell Cycle 4: 339-345, 2005.

26. MacPhail SH, Banath JP, Yu Y, Chu E and Olive PL: Cell cycle-dependent expression of phosphorylated histone H2AX: reduced expression in unirradiated but not X-irradiated G1phase cells. Radiat Res 159: 759-767, 2003.

27. Barzilai A and Yamamoto K: DNA damage responses to oxidative stress. DNA Repair 3: 1109-1115, 2004.

28. Nohl H: Generation of superoxide radicals as byproducts of cellular respiration. Ann Biol Clin 52: 199-204, 1994.

29. Moller P and Loft S: Interventions with antioxidants and nutrients in relation to oxidative DNA damage and repair. Mutat Res 551: 79-89, 2004.

30. Vilenchik MM and Knudson AG: Endogenous DNA doublestrand breaks: Production, fidelity of repair, and induction of cancer. Proc Natl Acad Sci USA 100: 12871-12876, 2003.

31. Kurose A, Tanaka T, Huang X, Halicka HD, Traganos F, Dai W and Darzynkiewicz Z: Assessment of ATM phosphorylation on Ser-1981 induced by DNA topoisomerase I and II inhibitors in relation to Ser-139-histone H2AX phosphorylation, cell cycle phase and apoptosis. Cytometry 68A: 1-9, 2005.

32. McManus KJ and Hendzel MJ: ATM-dependent DNA-damage independent mitotic phosphorylation of $\mathrm{H} 2 \mathrm{AX}$ in normally growing mammalian cells. Mol Biol Cell 16: 5013-5025, 2005.

33. Ichijima Y, Sakasai R, Okita N, Asahina K, Mizutani S and Teraoka H: Phosphorylation of histone $\mathrm{H} 2 \mathrm{AX}$ at $\mathrm{M}$ phase in human cells without DNA damage response. Biochem Biophys Res Commun 336: 807-812, 2005.

34. Juan G, Pan W and Darzynkiewicz Z: DNA segments sensitive to single strand specific nucleases are present in chromatin of mitotic cells. Exp Cell Res 227: 197-202, 1996.
35. Darzynkiewicz Z, Traganos F, Sharpless T and Melamed MR Different sensitivity of DNA in situ in interphase and metaphase chromatin to heat denaturation. J Cell Biol 73: 128-138, 1977.

36. Dobrucki J and Darzynkiewicz Z: Chromatin condensation and sensitivity of DNA in situ to denaturation during cell cycle and apoptosis. A confocal microscopy study. Micron 32: 645-652, 2001.

37. Williams MC, Pant K and Karpel RL: Single molecule force spectroscopy studies of DNA denaturation by T4 gene 32 protein. Spectroscopy 18: 203-211, 2004.

38. Kaneko H, Igarashi K, Kataoka K and Miura M: Heat shock induces phosphorylation of histone H2AX in mammalian cells. Biochem Biophys Res Commun 328: 1101-1106, 2005.

39. Sablina AA, Budanov AV, Ilyanskaya GV, Agapova L, Kravchenko JE and Chumakov PM: The antioxidant function of the p53 tumor suppressor. Nat Med 11: 1306-1313, 2005.

40. Kc S, Carcamo JM and Golde DW: Antioxidants prevent oxidative DNA damage and cellular transformation elicited by the over-expression of c-MYC. Mutat Res 593: 64-79, 2006.

41. Oikawa S, Yamada K, Yamashita N, Tada-Oikawa A and Kawanishi S: N-acetylcysteine, a cancer chemopreventive agent, causes oxidative damage to cellular and isolated DNA. Carcinogenesis 20: 1485-1490, 1999.

42. Schriner SE, Linford NJ, Martin GM, Treuting P, Ogburn CE, Emond M, Coskun PE, Ladiges W, Wolf N, Van Remmen H, Wallace DC and Rabinovitch PS: Extension of murine life span by overexpression of catalase targeted to mitochondria. Science 308: 1875-1876, 2005.

43. Albino AP, Huang X, Yang J, Gietl D, Jorgensen E, Traganos F and Darzynkiewicz Z: Induction of histone H2AX phosphorylation in A549 human pulmonary epithelial cells by tobacco smoke and in human bronchial epithelial cells by smoke condensate: A new assay to detect the presence of potential carcinogens in tobacco. Cell Cycle 3: 1062-1068, 2004.

44. Albino AP, Huang X, Jorgensen E, Gietl D, Traganos F and Darzynkiewicz Z: Induction of DNA double-strand breaks in A549 and normal human pulmonary epithelial cells by cigarette smoke is mediated by free radicals. Int J Oncol 28: 1491-1505, 2006. 